\title{
Influence of Local Mineral Raw Materials On The Commercial Success of Aveiro Production of Ancient Ceramic Sugar Jars
}

Rocha Fernando ( $\nabla$ tavares.rocha@ua.pt)

University of Aveiro https://orcid.org/0000-0002-3636-3933

Paulo Morgado

Universidade de Aveiro Departamento de Geociencias

\section{Research Article}

Keywords: ceramic sugar jars, mineral raw materials, mineralogy, geochemistry

Posted Date: July 30th, 2021

DOI: https://doi.org/10.21203/rs.3.rs-703908/v1

License: (c) (1) This work is licensed under a Creative Commons Attribution 4.0 International License.

Read Full License 


\section{Abstract}

Sugar forms were conic ceramic jars having a hole at the bottom, being used specifically for the stage of the purge of the sugar cake. These pieces played a paramount role in sugar production cycle, being used for the maturation of the sugar, and since the 15th until the beginning of the 19th centuries, the old pottery centres from Aveiro and Lisbon regions, produced heavily these "formas de açúcar" ("sugar jars") which were exported to sugar production areas, at places as diverse as Madeira, Canaries, Cape Verde, Cuba and Brazil. Mineralogical analysis by $\mathrm{x}$-ray powder diffraction was carried out on bulk samples. Chemical composition was assessed by X-Ray fluorescence. The obtained results gave important information about the composition of the studied materials, and also about their raw materials. Mineralogical and chemical data obtained in samples from Aveiro point to a local production, using the upper Cretaceous (Maastrichian) marly (dolomitic) clays and clayey sands as main raw materials. Ceramics from Barreiro (Lisbon) are in general more silicated and less carbonated, composition close to the Tagus Cenozoic Basin clays. The higher iron content of Aveiro clays favours the glazing of ceramic paste at lower temperatures, giving better mechanical resistance which can justify "their best quality", as referred to in ancient documents.

\section{Introduction}

Mineralogical and geochemical techniques have proved their soundness in the investigation of the provenance and technology of archaeological ceramics (Bonis et al. 2018, Prudêncio and Dias 2014, Rocha and Morgado 2014). Actually, local geology is crucial to the identification of potential raw materials for the ceramic manufacturing. A combination of several analytical techniques can contribute to the identification and characterization of a ceramic raw material. Recognition of the source raw materials in ceramics involves a complex array of provenance studies. Provenance studies that include mineralogical and/or geochemical fingerprinting are common in applied clay geology and sedimentary geology and can be also applied to reach this project goals.

"Sugar Jars" ceramics are recognized for their peculiar typology (Fig. 1), having conical shape, walls of great thickness, absence of flat base and presence of an orifice at the apex.

They were essential parts in the sugar production process (Fig. 2), which justified its large-scale use in the various producing areas (Barros et al. 2006, Morgado et al. 2012, Sousa 2006, Lourenço and Bugalhão 2006). This ceramic element characterized a time when sugar had great value in world trade. Portugal dominated a good share of this market thanks to its colonies, bringing great wealth to the country.

Till now, 2 producing sites (of these ceramics) are known on mainland Portugal: Barreiro (Barros et al. 2006) and Aveiro (Morgado et al. 2012). Recent investigations on occurrences of Mata da Machada (Barreiro), including ceramic ovens, numerous discoveries in Aveiro urban area, including entire pieces used as construction material on building walls (Fig. 3) have provided rich and varied set of samples available for laboratory studies. 
Barreiro production was perfectly included on the pendular trade between Lisbon and the Colonies, but the export of Aveiro production, then just a small city of reduced consumption, meant a purposeful coming of practically empty ships (which is evidenced by the existence of ballast stone from those ships in historical buildings of the city, rich in clays but poor in stone for construction). Thus, we can presume that Aveiro production would have distinctive technical characteristics (certainly related to local raw materials) that justified this purposeful coming.

This work aims to study in detail the influence of mineral raw materials (from both manufacturing sites) on the technical characteristics of produced ceramics, as well as on the technological development of production processes. For this purpose, we propose sedimentological, mineralogical and geochemical studies of geological formations in whose outcrops exploitation of the raw materials were performed (Xanthopoulos et al. 2020, Trindade et al. 2010a, 2010b, 2013, Daoudi et al. 2018), followed by a study of ceramics found on the 2 production sites (Aveiro and Barreiro), seeking to identify technological changes in their production and in the second to confirm origin and eventual differences in use (Prudêncio and Dias 2014, Rocha and Morgado 2014, Christidis et al. 2014, Montana 2020, Hein and Kilikoglou 2020, Cordell et al. 2017, Weiner et al. 2020).

Archeometry studies have been dominated by dating, technological characterization and provenance tests, especially of inorganic materials such as stone, ceramics and metals (Prudêncio and Dias 2014, Rocha and Morgado 2014). Studies of origin of archaeological ceramics through analysis of their elemental composition are based on assumption that raw materials can be distinguished through appropriate methodological approach integrating mineralogy and geochemistry (Christidis et al. 2014, Hein and Kilikoglou 2020, Montana 2020). Therefore, it's important to identify, characterize and distinguish potential raw materials, transformed and altered/degraded, and to test the reconstruction of their history of selection, manufacture, uses and changes after application (Cordell et al. 2017). The ceramic process is essentially thermal, producing phase changes, so it can be approached as inducing polymorphism, diagenesis and metamorphism (Weiner et al. 2020), with mineralogical transformations having a potential temperature marker value and comparative analyses between ceramic product and possible raw material to have a "reverse engineering" character (Xanthopoulos et al. 2020).

In the case of ceramics of the pottery center of Aveiro, preliminary studies on historical-documentary analyses were made, estimation of dating by stratigraphic analysis, macroscopic analysis with morphological and typological study, estimation of cooking atmosphere, chromatographic study and textural analysis (Morgado et al. 2012, Morgado 2009, Nobre 2017). Some mineralogical analysis by XRD were also done, allowing a first estimation of firing temperature; chemical analysis were performed by $\mathrm{X}$ ray fluorescence spectrometry (FRX) as well as some simple dynamic compression tests to assess the mechanical resistance (Morgado et al. 2012, Nobre 2017, Moutinho et al. 2019). To achieve our goals it will be important to study in detail the mineralogical and physical-chemical properties of ceramics and raw materials (Xanthopoulos et al. 2020).

\section{Materials And Methods}


The studied ceramics were found at a sub aquatic archaeological site in a channel of Aveiro coastal lagoon, allowing us to obtain some integrally preserved forms, and also in 8 sites corresponding to old buildings located in Aveiro urban areas where they were used as construction materials, normally as fragments, but with some walls constructed with fully integral forms added with traditional mortars.

In 1980 a Pottery Center was discovered in the middle of Mata da Machada (Barreiro) forest, being excavated the first furnaces known in Portugal from XV/XVI century. The ceramic pieces exhumed led to the identification of the parts produced including building materials (brick and tile) and industrial ceramics (cookie shapes and forms of Sugar Loaf). The dating of the period of operation of the furnace lies between approximately 1450 and 1530, granted by Numismatic pieces. At Santo António da Charneca (Barreiro), an ancient pottery was identified in 1997, found during the development of an urbanization. Among the pieces collected stands out a significant set of fragments of forms of sugar loaf. From well dated archaeological stratigraphy, it is possible to state that the period of operation of the furnace is situated between the end of the XV and middle of the XVI centuries. It was also collected a coin of Manuel I, king of Portugal (1495/1521).

Twenty Aveiro ceramics samples were selected for this study, being 5 from the sub aquatic archaeological site and 15 from several different urban sites. 15 ceramic samples from Barreiro 2 sites were also studied. Sampling was also done on Aveiro and Barreiro local outcrops of the regional lithological units know as having been (some still being) exploited for ceramics production.

In the Aveiro region (Fig. 4) there are huge deposits of heavy clays that belong to the geological formation "Argilas de Aveiro", dated of the Upper Cretaceous (Campanian-Maastrichtian according to Teixeira and Zbyszewski 1976).

The pottery of Santo António da Charneca and Mata da Machada (Fig. 5), both from the 15th-16th centuries, are located on the Marco Furado quaternary geological formation (QMF on geological maps), being considered as the main source of ceramic raw materials together with local Pliocene layers, as more recently by industrial ceramic plants (Barros et al. 2006). Both formations are illite-kaolinite clays/clayey sands, the quaternary richer in illite whereas the pliocene is richer in kaolinite.

Mineralogical analyses of ceramic pieces (total sample) and clay fractions under $0.063 \mathrm{~mm}$ and 0.002 mm were carried out by X-Ray diffraction, using a Panalytical X'Pert-Pro MPD, Ka Cu $(\lambda=1,5405 \AA)$ radiation on random-oriented powders (total sample and $<0.063 \mathrm{~mm}$ ) and oriented aggregates ( $<$ $0.002 \mathrm{~mm}$ ). The oriented aggregates were treated with glycerol and exposed to heat-treatment at $500^{\circ} \mathrm{C}$. Mineralogical composition was assessed using (hkl) peaks (on random powder mounts) for non clay minerals and (00I) ones (on oriented aggregates) for clay minerals; the identification of the different mineral phases followed the criteria recommended by Brindley \& Brown (1980) and the Joint Committee for Powder Diffraction Standards. The mineralogical semiquantification of the identified minerals was made through peak areas determination of the specific reflections (Brindley and Brown 1980) and was calculated following the "reflective powers method" according to Galhano et al. (1999) and Oliveira et al. (2002). 
Determination of chemical composition was assessed by X-Ray fluorescence using a Panalytical Axios PW4400/40 for major and trace elements; Lost on Ignition (LOI) was also determined (heated at $1000^{\circ} \mathrm{C}$ for 2 hours).

\section{Results And Discussion}

The mineralogical composition of the studied ceramics and clayey raw materials (Table 1) shows a predominance of silicate detrital minerals, such as quartz, feldspars and phyllosilicates, accompanied by, as accessories, goethite and hematite, calcite and dolomite. The clay fractions of the raw materials show illite as the main mineral, accompanied by kaolinite, with smectite (and illite-smectite) on smaller amounts.

Table 1 - Mineralogical composition (clay fraction composition in italic).

\begin{tabular}{|llllll|}
\hline & $\begin{array}{l}\text { Aveiro } \\
\text { Cretaceous } \\
\text { clays }\end{array}$ & $\begin{array}{l}\text { Barreiro Quaternary } \\
\text { sandy clays }\end{array}$ & $\begin{array}{l}\text { Barreiro } \\
\text { Pliocene } \\
\text { clayey } \\
\text { sands }\end{array}$ & $\begin{array}{l}\text { Aveiro } \\
\text { ceramics }\end{array}$ & $\begin{array}{l}\text { Barreiro } \\
\text { ceramics }\end{array}$ \\
\hline Quartz & $30-35$ & $40-45$ & $45-55$ & $35-40$ & $45-50$ \\
\hline K-Feldspars & $5-8$ & $5-7$ & $6-8$ & $5-10$ & $5-10$ \\
\hline Plagioclases & $3-6$ & $3-5$ & $3-6$ & $3-5$ & $4-8$ \\
\hline Phyllosilicates & $45-50$ & $35-40$ & $25-30$ & $35-40$ & $30-40$ \\
\hline Calcite & $3-5$ & $<2$ & $<2$ & $3-5$ & $<2$ \\
\hline Dolomite & $5-8$ & - & - & $6-8$ & - \\
\hline Hematite & $3-5$ & $2-3$ & $3-4$ & $6-10$ & $5-8$ \\
\hline Goethite & $4-7$ & $4-6$ & $3-5$ & - & - \\
\hline Mullite & - & - & - & $<2$ & - \\
\hline Illite & $50-55$ & $60-70$ & $55-65$ & & \\
\hline Kaolinite & $30-40$ & $20-25$ & $25-35$ & & \\
\hline Smectite & $10-15$ & $5-10$ & $<5$ & & \\
\hline
\end{tabular}

Comparing with Barreiro raw materials, Aveiro Cretaceous clays are richer in phyllosilicates and slightly poorer in quartz; other distinctive features are the relative higher content in carbonates (with exclusive presence of dolomite), and slightly higher presence of goethite and hematite.

Concerning clay minerals content, all clayey raw materials are illite rich but Aveiro Cretaceous clays show the highest content in kaolinite (along some smectite), whereas Barreiro Quaternary sandy clays are those 
richer in illite, Barreiro Pliocene clayey sands showing an intermediate clay composition.

All Aveiro studied ceramics show a mineralogical composition very similar to traditional bricks produced in Aveiro, from Cretaceous clays: quartz, phyllosilicates (mainly micas), feldspars (mainly K-feldspars), Fe-oxides (mainly hematite), carbonates (mainly dolomite). They show some distinctive features, such as: relative lower content on phyllosilicates (and almost exclusively micas) and a discrete presence of mullite in some samples.

Studied Barreiro ceramics show significant differences towards Aveiro ones, such as: more quartz, less phyllosilicates, less Fe-oxides, no carbonates and no mullite.

Table 2 shows chemical results (major elements) of the studied ceramics and clayey raw materials.

Table 2

- Chemical composition of the studied ceramics and clayey raw materials.

\begin{tabular}{|llllll|}
\hline & $\begin{array}{l}\text { Aveiro } \\
\text { Cretaceous clays }\end{array}$ & $\begin{array}{l}\text { Barreiro Quaternary } \\
\text { sandy clays }\end{array}$ & $\begin{array}{l}\text { Barreiro } \\
\text { Pliocene } \\
\text { clayey } \\
\text { sands }\end{array}$ & $\begin{array}{l}\text { Aveiro } \\
\text { ceramics }\end{array}$ & $\begin{array}{l}\text { Barreiro } \\
\text { ceramics }\end{array}$ \\
\hline $\mathrm{SiO} 2$ & $50-65$ & $60-75$ & $60-65$ & $60-70$ & $65-75$ \\
\hline $\mathrm{Al} 2 \mathrm{O3}$ & $19-21$ & $15-18$ & $17-20$ & $19-21$ & $16-18$ \\
\hline $\mathrm{K} 20$ & $3-6$ & $4-7$ & $4-6.5$ & $2-5$ & $2-6.5$ \\
\hline $\mathrm{Na} 20$ & $0.3-1$ & $0.5-1.2$ & $0.4-1$ & $0.2-1$ & $0.5-1.2$ \\
\hline $\mathrm{CaO}$ & $0.4-1.1$ & $0.2-0.7$ & $0.2-0.5$ & $0.3-1$ & $0.2-0.6$ \\
\hline $\mathrm{Fe} 2 \mathrm{O} 3$ & $4-9$ & $3-5$ & $3-6$ & $5-10$ & $4-6$ \\
\hline $\mathrm{MgO}$ & $2-3$ & $0.3-0.9$ & $0.3-0.7$ & $1.5-2.5$ & $0.6-0.8$ \\
\hline $\mathrm{TiO} 2$ & $0.5-1$ & $0.3-07$ & $0.3-0.6$ & $0.5-1$ & $0.3-0.7$ \\
\hline $\mathrm{LOI}$ & $8-10$ & $4-8$ & $4-7$ & $<2$ & $<3$ \\
\hline
\end{tabular}

Raw materials show chemical compositions in accordance with their mineralogical compositions and reflecting their main differences. Aveiro clays, being richer in phyllosilicates and with less quartz, show naturally less amounts in $\mathrm{SiO} 2$ and slightly higher in $\mathrm{Al} 2 \mathrm{O} 3$ and LOl; they show also relative higher contents in $\mathrm{MgO}$ (due to dolomite presence) and Fe2O3 (due to hematite and goethite). On the other hand, Barreiro raw materials are richer in $\mathrm{SiO} 2$ and slightly in alkalis.

All Aveiro ceramic samples show a chemical composition close to traditional bricks produced in Aveiro (Coroado et al. 1998), but with some relevant differences, such as: relative higher content in SiO2 and $\mathrm{Al} 2 \mathrm{O} 3$ and a discrete trend to show higher $\mathrm{Fe} 2 \mathrm{O} 3$ content. Barreiro ceramics show SiO2 higher content, Al2O3 and Fe2O3 lower contents and $\mathrm{CaO}$ (and MgO) very lower contents. Actually, mineralogical 
composition of Aveiro sugar jars are quite similar to local red ceramics typical raw materials, historically exploited on Upper Cretaceous marly (dolomitic) clays, in which the common clay minerals association is kaolinite plus illite, in some more red layers followed by illite-smectite, and usually also rich in goethite and hematite.

The persistence of dolomite is coherent with this maximum firing temperature $\left(\approx 800^{\circ} \mathrm{C}\right)$ which is not sufficient to achieve the total decomposition of this mineral that currently occurs in the local clays (Trindade et al. 2010 b); dolomite is absent or very discrete in heavy clays of any other Portuguese clay deposit (Coroado et al. 1998, Marques et al. 2011, Trindade et al. 2013).

On the other hand, the relative lower content on phyllosilicates as well as the discrete presence of mullite in some samples, points to a firing temperature slightly higher (more kaolinite, later production).

Red clays (commonly more kaolinitic) should have been increasingly used in advantage over green clays. Red clays are also richer in Fe-oxides, whereas green clays are richer in dolomite. Relative higher content on $\mathrm{Si}$ and $\mathrm{Al}$, as well as the discrete trend to show higher Fe contents, shown by the same samples referred previously, reinforces this consideration (Amaral et al. 2020). It is well known that high iron contents favors the vitrification of the ceramic bodies at lower temperatures, which able the ceramic bodies to acquire good values of mechanical resistance at lower firing temperatures (Amaral et al. 2020, Moutinho et al. 2019); compressive strength analysis of Aveiro ceramics sugar jars pieces shows higher values (mean 9.5 MPa) (Moutinho et al. 2019).

Mineralogical and chemical composition of Lisbon (Barreiro) sugar jars are also quite similar to local red ceramics typical raw materials, historically exploited on Barreiro (portuguese word for clay quarry) Pliocene sandy clays, in which the common clay minerals association is illite + kaolinite + smectite. On Lisbon (Barreiro) sugar jars, the absence of high temperature phases, as well as the poor contents on $\mathrm{Fe}$ oxides, explains the lower quality of the firing products.

\section{Conclusions}

The obtained results have given important information about the composition of the studied ceramics, and also about their raw materials.

Chemical and mineralogical characteristics of Aveiro and Barreiro ceramics are similar to surrounding clayey formations, pointing to local production using only local raw materials.

Ceramic pieces from Aveiro are well related with upper Cretaceous (Maastrichian) marly (dolomitic) clays and clayey sands, whereas ceramics from Barreiro (Lisbon) are in general more silicated and less carbonated, composition close to Pliocene clayey sands and Quaternary sandy clays.

The higher iron content of Aveiro clays favours the glazing of ceramic paste at lower temperatures, giving them better mechanical resistance (Moutinho et al. 2019) which can justify "their best quality", as referred to in ancient documents. 


\section{Declarations}

Funding: This research was supported by funds from the Research Unit GeoBioTec (FCT - Fundação para a Ciência e a Tecnologia, Portugal - UIDB/04035/2020).

Conflicts of interest/Competing interests: none

Availability of data and material (data transparency): materials and data at Geosciences Department, University of Aveiro, Portugal

\section{References}

1. Barros L, Cardoso G, Gonzalez A (2006) As Formas de Pão de Açúcar da Olaria de S. António da Charneca - Barreiro. in A Cerâmica do Açúcar em Portugal na Época Moderna, coord. Élvio Sousa, $36 \mathrm{pp}$

2. Bonis A, Arienzo I, D'Antonio M, Franciosi L, Germinario C, Grifa C, Guarino V, Langella A, Morra V (2018) Sr-Nd isotopic fingerprinting as a tool for ceramic provenance: Its application on raw materials, ceramic replicas and ancient pottery. J Archaeol Sci 94:51-59. https://doi.org/10.1016/j.jas.2018.04.002

3. Brindley GW, Brown G (1980) Crystal Structures of Clay Minerals and Their X-ray Identification. Mineralogical Society, Monograph No. 5, London, 495 pages

4. Christidis G, Shriner CM, Murray HH (2014) An integrated methodological approach for source-clay determination of ancient ceramics: the case of Aegina island, Greece. Clays Clay Miner 62(6):447469. https://doi.org/10.1346/CCMN.2014.0620601

5. Cordell A, Wallis NJ, Kidder G (2017) Comparative Clay Analysis and Curation for Archaeological Pottery Studies. Advances in Archaeological Practice 5(1):93-106. http://doi.org/10.1017/aap.2016.6

6. Coroado J, Marques JC, Rocha F, Gomes C (1998) Characterisation and ceramic properties of Bustos clay (Aveiro, Portugal). In Gomes C (ed) Proceedings of the 2nd Mediterranean Clay Meeting, Univ. Aveiro, Vol. 2: 375-380

7. Daoudi L, Rocha F, Costa C, Arrebei N, Fagel N (2018) Characterization of rammed-earth materials from the XVIth century Badii Palace in Marrakech, Morocco, to ensure authentic and reliable restoration. Geoarchaeology 33(5):529-541. https://doi.org/10.1002/gea.21671

8. Galhano C, Rocha. G (1999) Geostatistical analysis of the influence of textural, mineralogical and geochemical parameters on the geotechnical behavior of the "Aveiro Clays" formation (Portugal). Clay Miner 34:109-116. https://doi.org/10.1180/000985599545966

9. Hein A, Kilikoglou V (2020) Ceramic raw materials: how to recognize them and locate the supply basins - chemistry. Archaeological Anthropological Sciences 12:180. https://doi.org/10.1007/s12520-020-01129-8 
10. Lourenço S, Bugalhão J (2006) As Formas de Pão de Açúcar da llha da Berlenga, in Sousa E. (coord) A Cerâmica do Açúcar em Portugal na Época Moderna, 47-61

11. Marques R, Dias MI, Prudêncio MI, Rocha F (2011) Upper Cretaceous clayey levels from western Portugal (Aveiro and Taveiro regions): clay minerals and trace elements distribution. Clays Clay Miner 59(3):315-327. https://doi.org/10.1346/CCMN.2011.0590307

12. Montana G (2020) Ceramic raw materials: how to recognize them and locate the supply basins mineralogy, petrography. Archaeological and Anthropological Sciences, 12: 175. https://doi.org/10.1007/s12520-020-01130-1

13. Morgado PJ (2009) A Cerâmica do Açúcar em Aveiro na Época Moderna. ADERAV (ed), Aveiro

14. Morgado PJ, Silva RC, Filipe SJ (2012) A cerâmica do açúcar de Aveiro: recentes achados na área do antigo bairro das olarias" in Velhos e Novos Mundos. In: Teixeira A, Bettencourt J (eds) Estudos de Arqueologia Moderna. Centro de História de Além-Mar, Lisboa, pp 771-782

15. Moutinho S, Costa C, Cerqueira A, Sequeira C, Terroso D, Nobre J, Morgado P, Velosa A, Rocha F (2019) Ceramics Sugar Jars Pieces from Aveiro Production. 14th International Congress for Applied Mineralogy (ICAM2019), Springer Proceedings in Earth and Environmental Sciences, 483-484, https://doi.org/10.1007/978-3-030-22974-0_119

16. Nobre JMT (2017) Paredes pão-de-açúcar em edifícios de Aveiro Evolução, materiais e características. Unpublished MSc thesis, UNL, Lisbon

17. Oliveira A, Rocha F, Rodrigues A, Jouanneau J, Dias A, Weber O, Gomes C (2002) Clay minerals from the sedimentary cover from the Northwest Iberian shelf. Prog Oceanogr 52:233-247. https://doi.org/10.1016/S0079-6611(02)00008-3

18. Prudêncio MI, Dias MI (2014) Composição química, geoquímica, matérias-primas e peças cerâmicas. In Dinis PA, Gomes A, Monteiro Rodrigues S (eds.) Proveniência de materiais geológicos: abordagens sobre o Quaternário de Portugal. Associação Portuguesa para o Estudo do Quaternário, Coimbra, ISBN 978-989-97140-2-1, 87-96

19. Rocha F, Gomes $C$ (1995) Paleoenvironmental reconstruction of the Aveiro region during Cretaceous based on clay mineralogy. Cretac Res 16:187-194. https://doi.org/10.1006/cres.1995.1015

20. Rocha F, Morgado P (2014) Mineralogia, matérias-primas e peças cerâmicas. In Dinis PA, Gomes A, Monteiro Rodrigues S (eds.) Proveniência de materiais geológicos: abordagens sobre o Quaternário de Portugal. Associação Portuguesa para o Estudo do Quaternário, Coimbra, ISBN 978-989-97140-2$1,97-102$

21. Sousa E (2006) Cerâmica do Açúcar das Cidades de Machico e do Funchal. Dados Históricos e Arqueológicos para a Investigação da Tecnologia e da Produção Açucareira em Portugal. In Sousa E (ed) A Cerâmica do Açúcar em Portugal na Época Moderna, 19-25

22. Teixeira C, Zbyszewski G (1976) Carta Geológica de Portugal, 1/50 000. Notícia explicativa da Folha 16-A, Aveiro. Serviços Geológicos de Portugal

23. Trindade MJ, Rocha F, Dias MI (2010) Geochemistry and mineralogy of clays from the Algarve Basin, Portugal: a multivariate approach to palaeoenvironmental investigations. Curr Anal Chem 6(1):43- 
52. https://doi.org/10.2174/157341110790069682

24. Trindade MJ, Dias MI, Coroado J, Prudêncio MI, Rocha F (2010) Firing tests of clayey raw materials from the Algarve Basin (South Portugal): Study of the mineral transformations with temperature. Clays Clay Miner 58(2):188-204. https://doi.org/10.1346/CCMN.2010.0580205

25. Trindade MJ, Rocha F, Dias MI, Prudêncio MI (2013) Mineralogy and grain-size distribution of clay raw materials from Algarve. Portugal Clay Minerals 48(1):59-83.

https://doi.org/10.1180/claymin.2013.048.1.04

26. Xanthopoulos V, Iliopoulos I, Liritzis I (2020) Characterization techniques of clays for the archaeometric study of ancient ceramics: a review. Scientific Culture 6(2):73-86. http://doi.org/10.5281/zenodo.3724849

27. Weiner S, Nagorsky A, Feldman Y, Kossoy A (2020) Archaeological Ceramic Diagenesis: Clay Mineral Recrystallization in Sherds from a Late Byzantine Kiln. Israel Minerals 10:408. https://doi.org/10.3390/min10050408

\section{Figures}
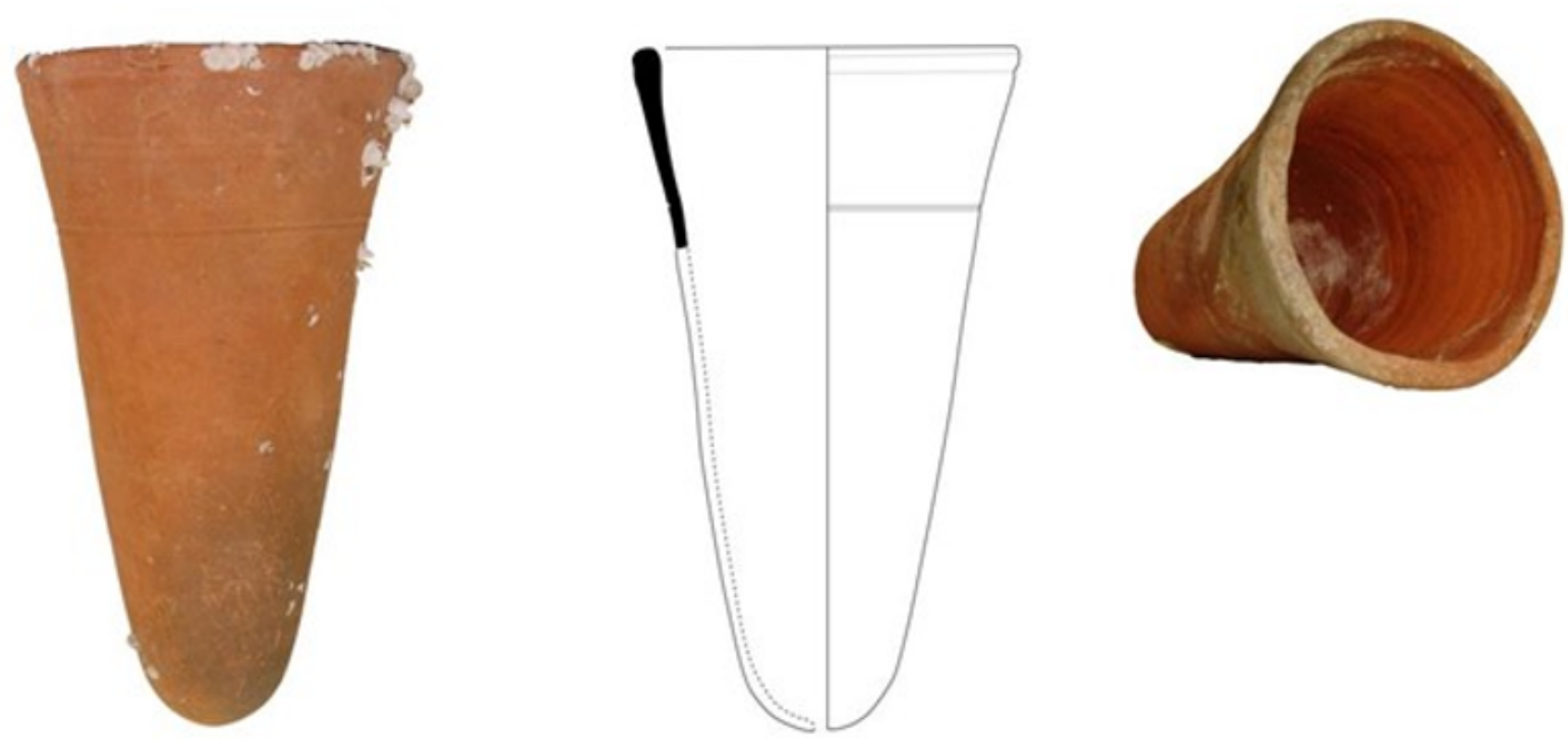

\section{Figure 1}

Ceramic sugar jars. 


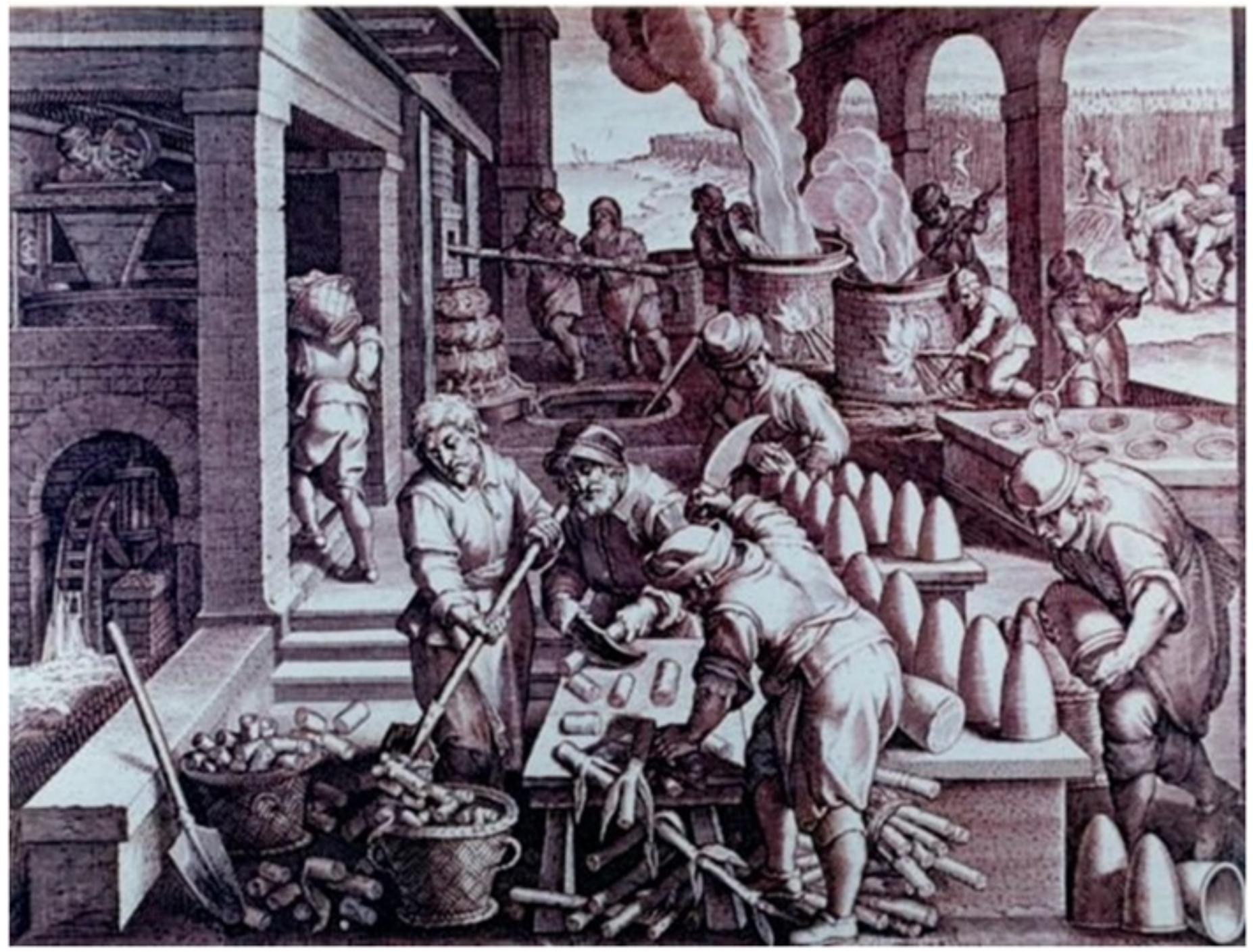

Figure 2

Old sugar production process. 


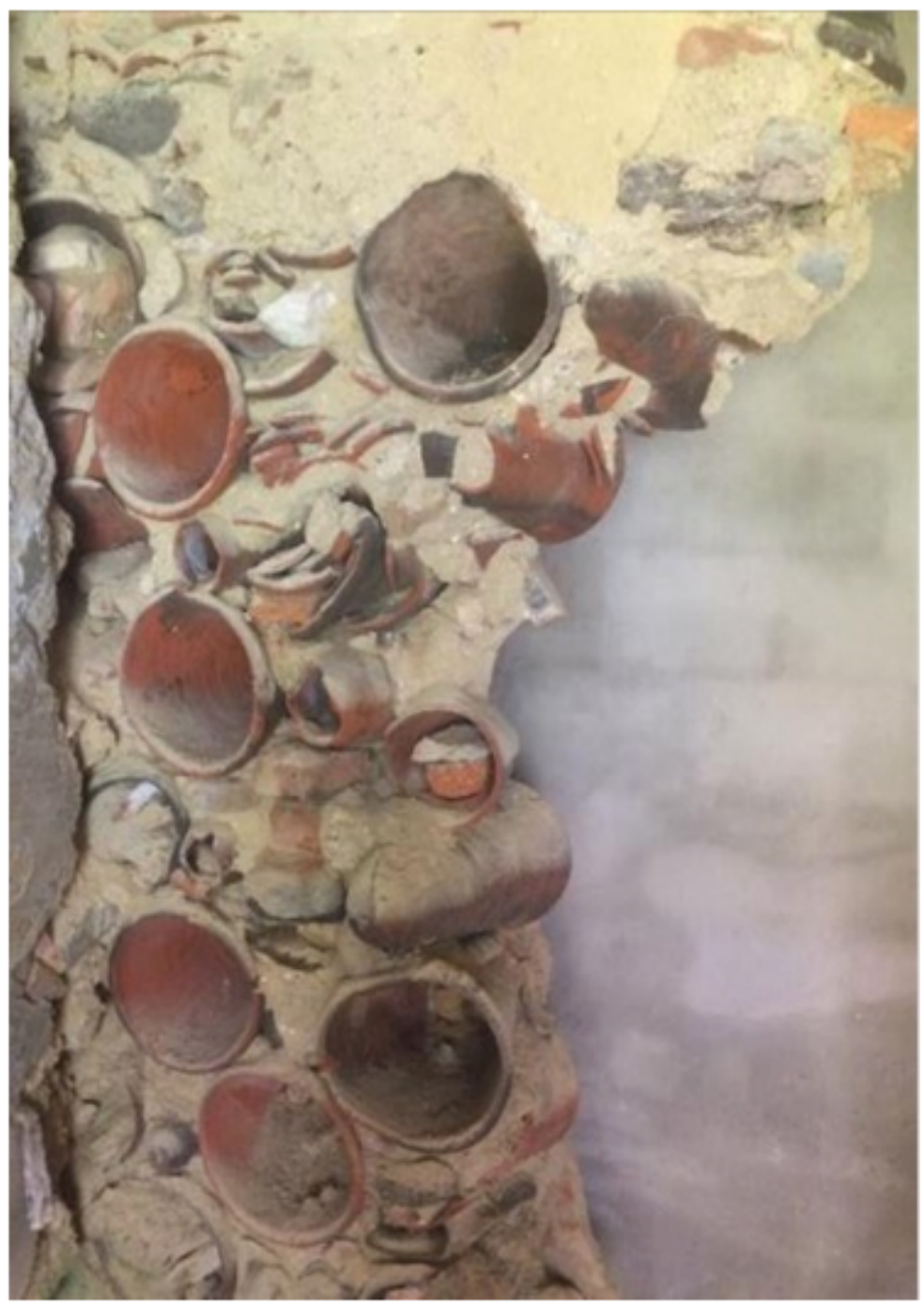

Figure 3

Sugar jars used as construction material on building walls. 


\section{Legend:}

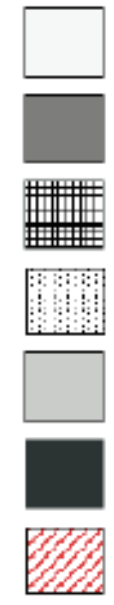

Cenozoic

Campanian-Mastrichtian

Coniacian-Santonian

Aptian/Albian-Cenomanian-Turonian

Jurassic

Triassic

Palaeozoic-Proterozoic

(-) Sampling sites
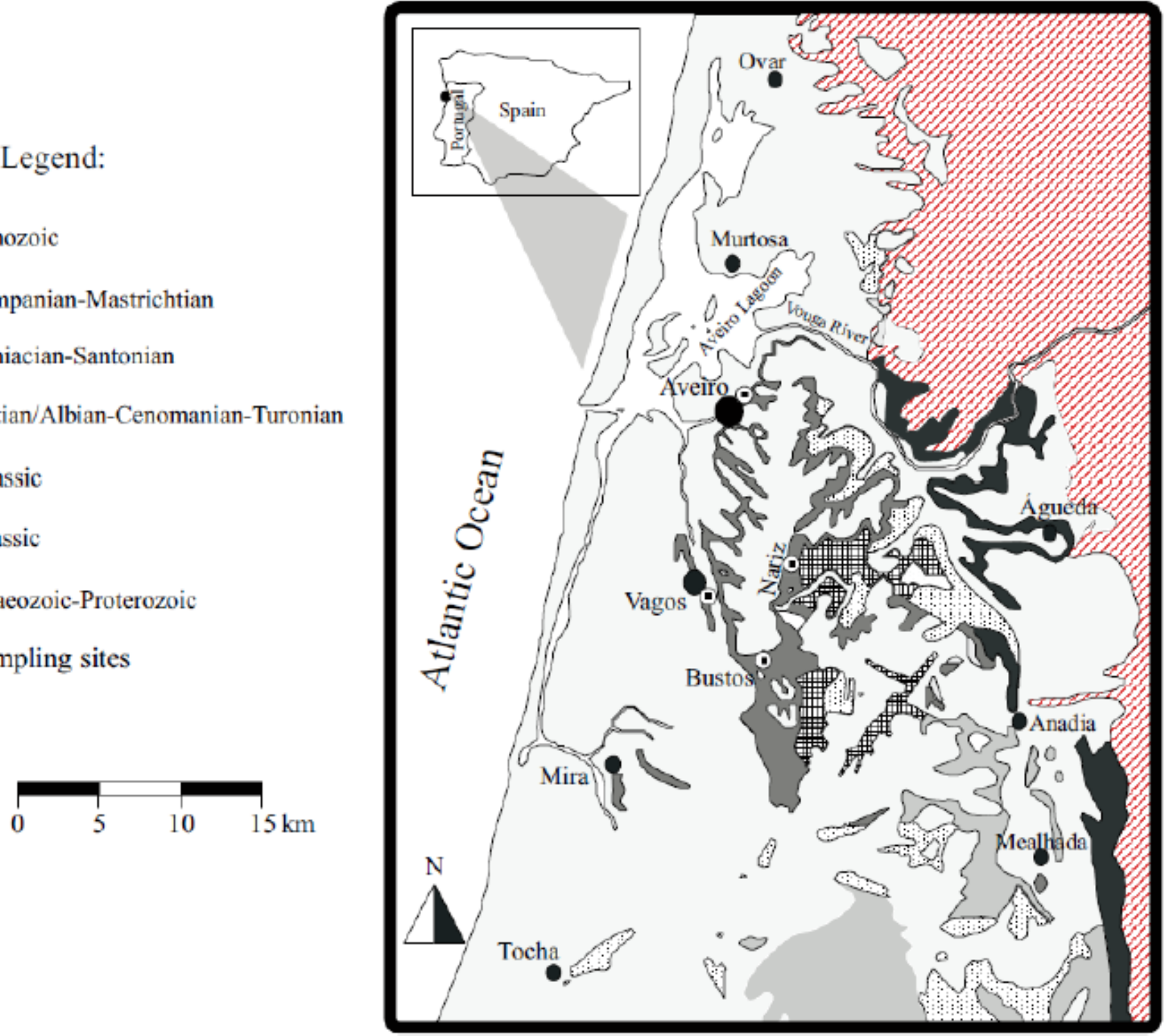

\section{Figure 4}

Aveiro sampling site location and geological setting (from Galhano et al. 1999). 


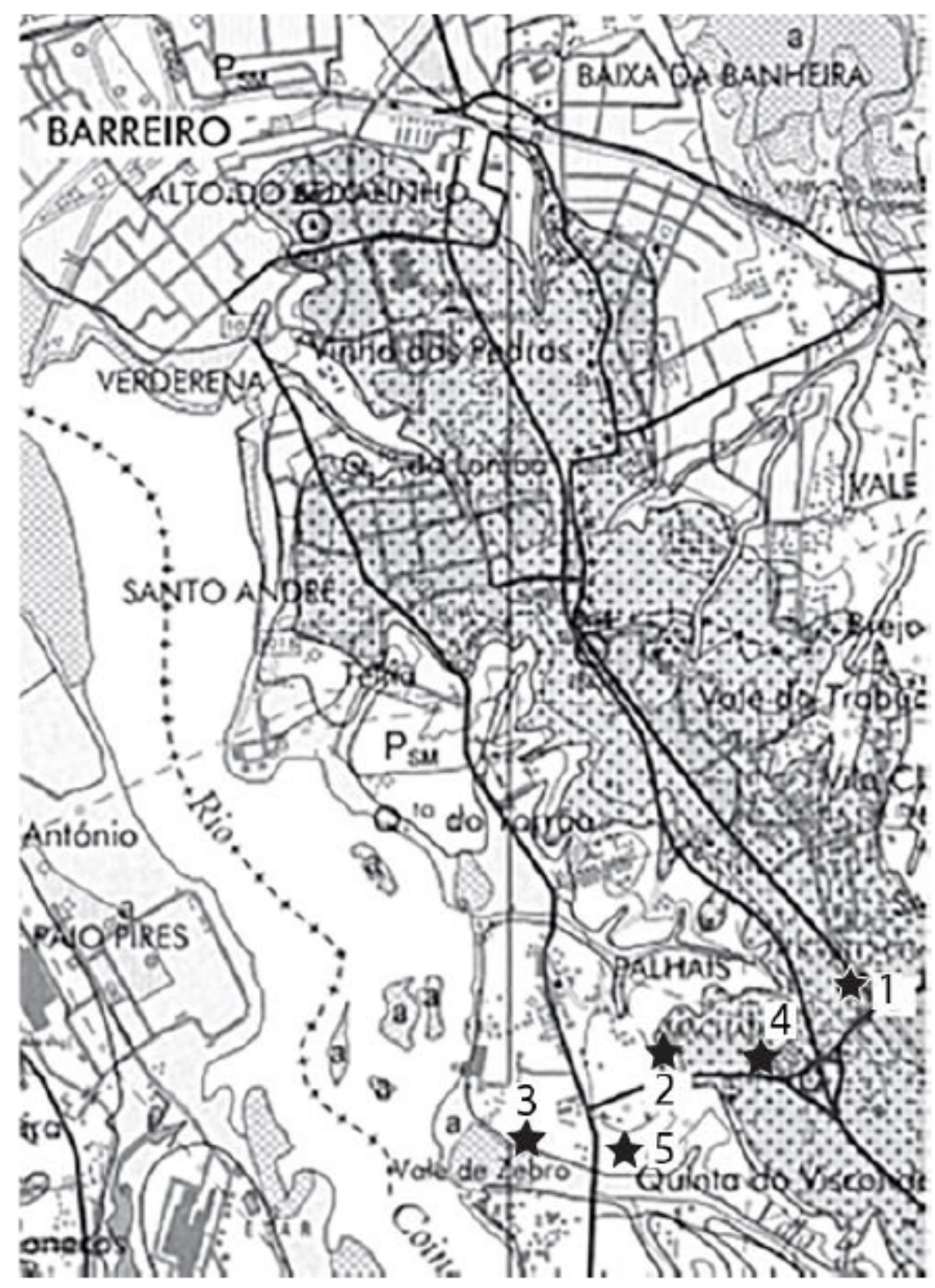

Figure 5

Barreiro sampling site location and geological setting (adapted from Barros et al. 2006). 